\section{Flying Kites, Nazi Ideology and Collaborative Mapping: Coping with Rightwing-Extremism in Secondary Education}

Gl_Forum 2017, Issue 2

Page: 23 - 35

Full Paper

Corresponding Author:

michael.lehner@sbg.ac.at

DOI: 0.1553/giscience2017_02_s23

Michael Lehner, Thomas Jekel and Robert Vogler

Department of Geography and Geology \& PLUS-School of Education, University of Salzburg

\begin{abstract}
In Austria and Germany, one of the more recent political shifts has been a swing towards the extreme right (AfD, 'Identitäre'), accompanied by a change in what is seen as acceptable in language. Right-wing movements have come more into the open, straddling the fence around what is forbidden under Austrian and German law. Symbols forbidden by laws designed to prevent a reproduction of NSDAP institutions and ideology can regularly be seen in public spaces. This paper presents an initiative triggered by one of these open representations of Nazi ideology in November 2016, when two men flew a children's kite in Salzburg city-centre. The kite was decorated with 4 different Nazi symbols. Using Instagram, the initiative maps such symbols collected by the public and extracts location information for representation in ArcGIS-Online. We show how this initiative can contribute to the formation of the political subject and discuss teaching methods, the technical development of the project, and initial results.
\end{abstract}

\title{
Keywords:
}

Geography education; citizenship education; right-wing extremism, geomedia

\section{Introduction}

It was early November 2016, and two young men were about to fly a kite at the Müllner Steg in Salzburg, a central location where such an activity cannot typically be enjoyed. Even more unusual were the national-socialist symbols which covered the kite itself (Figure 1). Observing the situation, pedestrians alerted the local police, who intervened based on the Prohibition Act and the Insignia Act (derStandard 2016). 


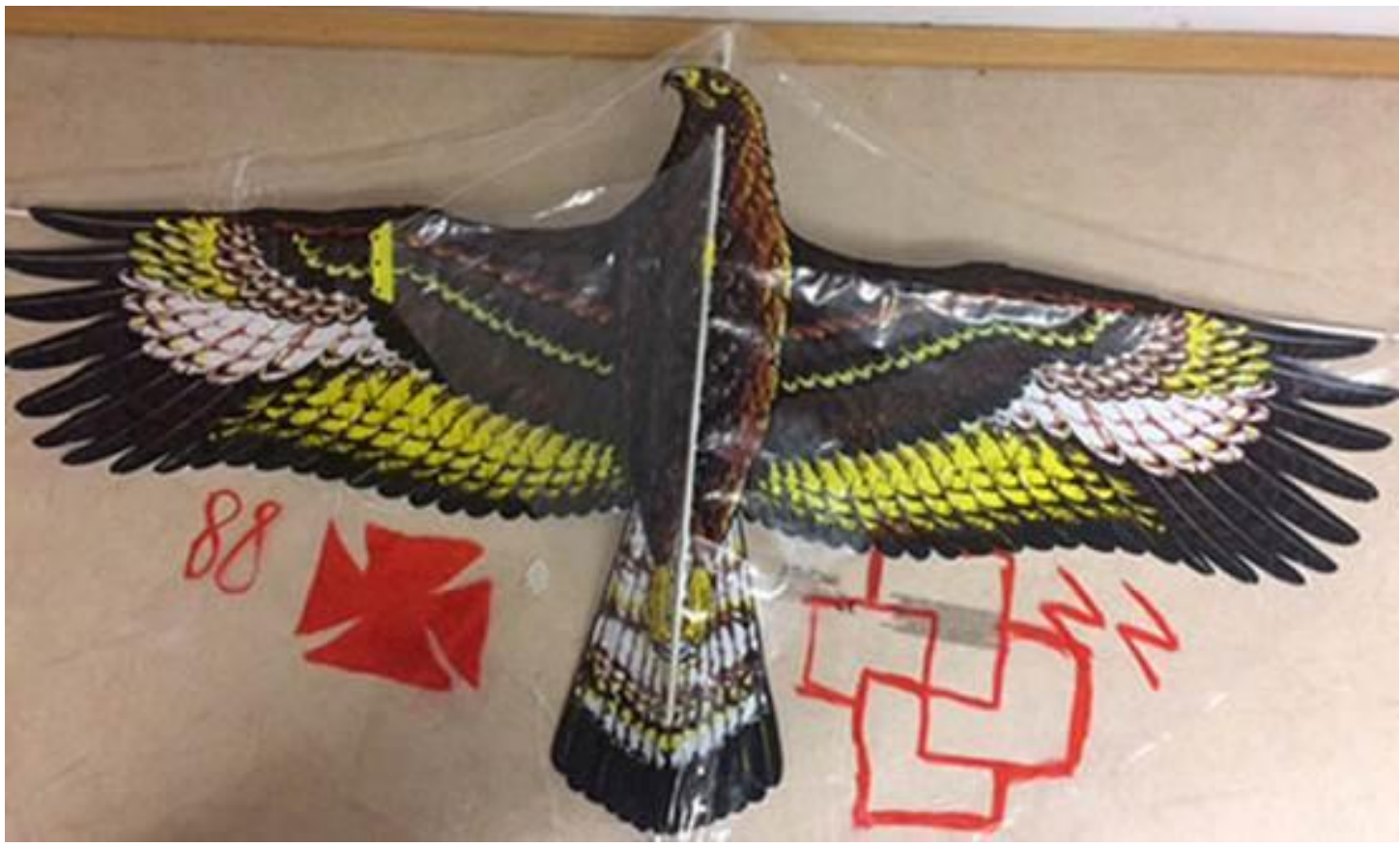

Figure 1: Kite with national-socialist symbols from 4.1 1.2017. Source: Landespolizeidirektion Salzburg

This display was the catalyst for the initiative '\#notmysymbol' against such right-wing symbols and expressions of extreme ideology in public spaces. The initiative, launched by the authors and presented here, intends not only to engage with countering right-wing extremism but also to contribute to the formation of the political subject through a collaborative mapping approach.

During the initial stages of the project we faced several questions, which can be divided into two topic areas. The first questions related to pedagogics of geography: how to effectively raise public awareness of a right-wing extremist production of space, and how we might teach and apply critical spatial thinking in relation to civic engagement. The second topic area referred to technical approaches, including how to collaboratively acquire data and how to visualize it using Geographic Information Systems (GIS).

Here, we present our answers to these questions and our initial results, and offer thoughts on possibilities for further research to expand our initiative. As a basis for this, we start with a discussion of the theoretical framework while highlighting concepts of right-wing extremism and the (regional) legal context. 


\section{Right-Wing Extremism: Concepts, Controversies and Perspectives}

The subject of right-wing extremism, as well as garnering significant media coverage, is also present to a considerable extent in the academic literature of various disciples: ${ }^{1}$ attempts are being made to observe this phenomenon from different perspectives, which is why discussion may also be accompanied by controversies. This section provides an insight into the debate and a reflection on the positioning of the \#notmysymbol initiative within these discourses. Therefore, two important positions are contrasted: 'extremism theory', and the approach that considers right-wing extremism as a 'syndrome phenomenon'.

\section{Extremism Theory}

A very prominent theoretical framework to understand right-wing extremism is that of extremism theorists such as Backes \& Jesse (1993) or Pfahl-Traughber (2013) and applied, for example, by the German Ministry of Constitutional Protection and the Interior (see BMI, 2016, pp. 25ff). In essence, the representatives of extremism theory oppose 'extremists' who refuse the 'values and rules of the game' of a constitutional democracy, and 'democrats' (see Backes \& Jesse, 1993, p. 40). 'Extremism' thus encompasses phenomena such as 'right-wing extremism', 'left-wing extremism', 'Islamism', 'Eco-terrorism' and 'radical feminism' (Jesse, 2004, p. 7).

Despite its widespread use, the theory of extremism has been widely criticized. It is considered to be empirically untenable. This can be attributed to some attitudinal studies showing that anti-democratic, racist and anti-semitic views can also be found in the 'social centre'. ${ }^{2}$ In defence of the theory of extremism, however, it can be said that the 'social centre' is necessarily a place where democracy and human rights are not threatened (Virchow et al., 2016). Furthermore, completely opposite phenomena such as 'right-wing' and 'leftwing extremism' would be subsumed and thus tendentially equated (see Glaser, 2012). In this case, not only would the 'social centre' be difficult to measure with shifts in the electorate, but all those political agendas going beyond current social conditions would be delegitimized at the same time (Weidinger, 2014, pp. 72ff). Above all, the theory of extremism could hardly contribute to an understanding of the phenomenon dealt with: it would merely describe it relationally with reference to what is considered the 'political centre' (Jaschke, 1991, p. 53). Pfahl-Traughber (2013, p. 48) recognizes this criticism and calls for further development, the need for which is still pending after more than 20 years (see PfahlTraughber 2013, pp. 17ff).

\section{Right-Wing Extremism as a 'Syndrome Phenomenon'3}

Despite the dominance of the theory of extremism, those concerned parties to whom this approach is not particularly familiar keep insisting on the concept of 'right-wing extremism',

\footnotetext{
${ }^{1}$ From 1990 to 2013, more than 5,000 scientific publications discussed the subject (see Frindte, Geschke, Haußecker, \& Schmidtke, 2016, pp.26ff).

2 This may also be referred to as 'extremism of the centre' (Kraushaar, 1994).

3 The term 'syndrome' is also used in medicine and psychology to describe a combination of various symptoms (see Duden 2006, p. 989)
} 
trying to define the phenomenon based on its characteristics. Austrian contributors to research (e.g. Schiedel, 2014) base themselves on the conceptual understanding of Holzer (1994) (see Weidinger, 2014). ${ }^{4}$

According to Holzer (1994), right-wing extremism is a 'syndrome phenomenon', understood as a bundle of inter-connected features (see Schiedel, 2014, p. 117), including:

- the principle of nature / naturalness / naturalization, which dismisses everything unwanted as 'unnatural'. In addition, social and global inequalities and their associated hierarchies are also legitimated by this principle (Holzer, 1994 pp. 34ff).

- 'Volk und Volksgemeinschaft' ('people and the people's community'), which attribute social groups with unchanging character traits, some of which are even super-ordinated to the individual (Holzer, 1994, pp. 35ff). Thus, pseudo-significance is gained by an individual through his or her obligation towards 'the totality of the people' (Bailer-Galanda, unknown year). It may be noted that these totalities are also linked to naturalized absolute spaces.

- Ethnocentrism and ethnopluralism: with this concept, a desire for a 'world-wide system of apartness' is expressed following the motto 'Germany to the Germans, Turkey to the Turks ...' This principle features the same integration and exclusionary functions as racism in the 1930s (see Holzer, 1994, p. 39; BailerGalanda, unknown year)

- Scapegoat function: groups such as 'strangers', but also academics or politicians within established parties, are blamed for misdeeds. This function becomes particularly important when some economically justified fears are projected onto enemy groups, allowing conspiracy theories to take the place of rational analyses (see Holzer, 1994, p. 53; Bailer-Galanda, unknown year).

- 'Nationalizing historiography': born from the view that the 'German people' would be superior, there is a tension between guilt about and glorification of the crimes committed in the name of this 'people' under the Nazi regime. The tension can be relieved through the trivialization or denial of these violent crimes (see Holzer, 1994, p. 55; Bailer-Galanda unknown year).

In summary, there are many counter-arguments to those of the theory of extremism - that is, the idea of a clearly definable 'right edge' on the one hand, and an idealized 'democratic centre' on the other. Last but not least, one might all too easily overlook the 'correspondences between the discourses of the extreme right and those of the political middle' (Virchow et al., 2016, p. 26).

The definition by Holzer also reveals that on the right-hand edge, spatially argued othering processes are strongly promoted. At the same time and in line with Lefebvre (1993) and Paasi (1986), the question may also be raised as to how the corresponding social groups symbolize their regionalization in public space. Flying a painted kite or painting the walls

\footnotetext{
${ }^{4}$ In the German debate about this approach, it is worth mentioning Jaschke (1994) and Holzer (1994), who are close to each other in their understanding of concepts. In the early 2000s, a definition of 'right-wing extremism' was developed by the 'consensus group' in order to make empirical investigations more comparable (see Kreis, 2007).
} 
with explicit symbols cannot be anything but that, even though many of these social markers have now been moved to a virtual space. ${ }^{5}$

For reasons of operationalization, the \#notmysymbol initiative is based on legal texts in the 'Aufruf (Cald) 6 and refers to 'prohibited national socialist symbols'. Although its conception is derived from the theory of extremism, in creating the title '\#notmysymbol' the most open formulation possible was chosen in order to invite discussion and reflection on one's own political conception of 'right-wing extremism'.

\section{$3 \quad$ Legal Basis}

In Austria, ${ }^{7}$ the legal basis of the initiative is provided by two Acts: the Prohibition Act of 1947, as amended, and the Insignia Act of 1960, as amended. The Prohibition Act extensively regulates the treatment of individuals directly involved in the national socialist rule after World War II. This part of the legislation is largely irrelevant for our project. However, $\$ 1$ and $\$ 3$ of the Prohibition Act refer to bans and ranges of punishment which are relevant to the \#notmysymbol project, namely the regulations dealing with the restoration of the NSDAP or its sub-organizations:

The NSDAP, its paramilitary groups (SS, SA, NSKK, NSFK), its subgroups and affiliated associations, as well as all National Socialist organizations and institutions in general have been dissolved and their re-establishment is forbidden.

( $(1$ Prohibition Act)

Anyone using printed works, radio or any other media to deny, grossly degrade, welcome, or justify publicly in a way accessible to many people the national socialist genocide or other national socialist crimes against humanity [will be punished with imprisonment of up to ten years, or up to 20 years for a particularly dangerous perpetrator ...].

( $(33$ Prohibition Act)

This provision includes the spread of national socialist symbols in public spaces. However, many court proceedings and sentences do not necessarily follow the Prohibition Act, but rather the related Insignia Act of 1960:

(1) Insignia, uniforms or parts of uniforms belonging to an organization prohibited in Austria are not allowed to be worn, displayed or disseminated in public. Emblems, symbols and markings shall also be considered as insignia.

\footnotetext{
${ }^{5}$ Examples of the preparation and deconstruction of virtual-spatial mappings are provided by www.hoaxmap.org (04/01/2016) and Fuchs (2016).

${ }^{6}$ Publicly available at http://bit.ly/notmysymbol.

${ }^{7}$ Here, the Austrian legal situation is presented. The German federal legal position with regards to national socialist symbols is stipulated in $\$ 86$ of the Criminal Code $(\mathrm{StGB})$, Propagation of Propaganda Means of Unconstitutional Organizations, and is very similar. The dissolution and liquidation of the NSDAP were regulated by the Control Council Act No. 2, the 'Dissolution and Liquidation of Nazi Organizations', of 10 October 1945 (http://www.verfassungen.de/de/de4549/kr-gesetz2.htm).
} 
(2) Because of their similarity or their obvious purpose, the prohibition stipulated in paragraph 1 also applies to insignia, uniforms and parts of uniforms used as substitutes for the badges, uniforms or parts of uniforms mentioned in paragraph 1.

( $(1$ Insignia Act, own translation)

Thus, $\$ 2$ also allows for the detection of symbols to, in clear intent, 'artistically' alienate them. $\int 2$ of the Insignia Act regulates the exceptions related to representations, and exhibitions in which the insignia mentioned are not at the centre of the representation. It states:

(2) The prohibitions stipulated in $\$ 1$ do not apply to other exhibitions if the exhibition and its purpose are clearly directed against the ideas of the relevant prohibited organization.

( $(2$ (2) Insignia Act, own translation)

This is precisely the stipulation that allows for the documentation of national socialist symbols in public spaces. In the case of \#notmysymbol, the 'exhibition' can be considered virtual by virtue of the fact that the image databases are in the cloud; each individual image is documented with the \#notmysymbol hashtag and a reference to a website (www.bit.ly/notmysymbol) which is clearly directed against national socialist ideas.

\section{Pedagogical foundation and initiating \#notmysymbol}

The launch of the \#notmysymbol initiative took place during the 'Introduction to geography and economics education' course at the University of Salzburg in 2016. After an introduction to the initiative, students were given two tasks:

1. The students had to search the city for right-wing extremist symbols and document them via smartphone using Instagram and the hashtag \#notmysymbol, with positioning services enabled in order also to document the location of the symbols found.

2. The students were presented with questions to provoke the expression of critical views concerning the project, of any problems encountered, or relating to the mapping strategies and potential interpretations of the symbols collected.

The theoretical framework for this initiative is rooted in three concepts of geography education and tries to answer questions such as how to visualize right-wing extremist production of space; how to raise public awareness; and how to teach and practise critical spatial thinking in relation to civic engagement in order to foster the formation of the political subject. The concepts 'Spatial Citizenship Education' (Gryl \& Jekel 2012) and 'Activist Citizenship Education' (Gordon, Mitchell \& Elwood 2016) provide an initial approach to these questions and therefore serve as the pedagogical basis for \#notmysymbol. They emphasize the potential of GIS-based collaborative mapping processes to impart social concepts of space. One of these concepts goes back to Lefebvre (1993), who basically says that a social reality which does not correspond to a spatial reality will not endure (see Werlen, 2008, p. 63). 
During the collaborative mapping process, the students applied Lefebvre's (1993) concept of the production of space: via critical spatial thinking they identified 'spaces of representation' while searching for right-wing extremist productions of space in the city of Salzburg. The students were quite often surprised by the diversity of the symbols, or 'spaces of representation', which they found, as the following comment shows:

I was quite impressed by the diversity of impressions I faced on my daily way to the university. I found graffiti, which were hardly decodable, and stickers of bands and football teams with political statements.

(comment of a student, female; own translation)

But Spatial Citizenship Education (Gryl \& Jekel, 2012) and Activist Citizenship Education (Gordon, Mitchell \& Elwood, 2016) try to go beyond a simple collaborative mapping exercise by encouraging critical spatial thinking. Therefore, the mapping process needs to be complemented by reflexivity (Gryl \& Jekel, 2012; Gordon, Mitchell \& Elwood, 2016).

One concept that can help to encourage reflexivity is the 'paradigm of traces' of Gerhard Hard (1995). He claims that a subject matter should be interpreted or read as a trace of or as evidence for something else (Hard, 1995, p. 33) - in our case, a piece of graffiti as a 'space of representation' (Lefebvre, 1993) for political ideas. Beyond that, Hard (1995) shows how the interpretation of 'traces' is a process of de- and reconstruction. ${ }^{8}$ An example of this process could be the interpretation of the images in Figures 2 and 3.

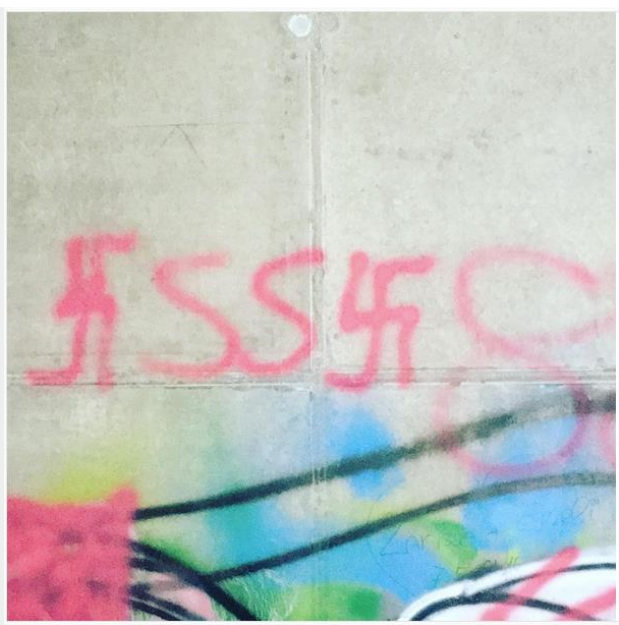

Figure 2: jo_anha

Makartsteg; \#notmysymbol; https://www.instagram.com/p/BNrOfBpg905/ (access: 2017-01-31)

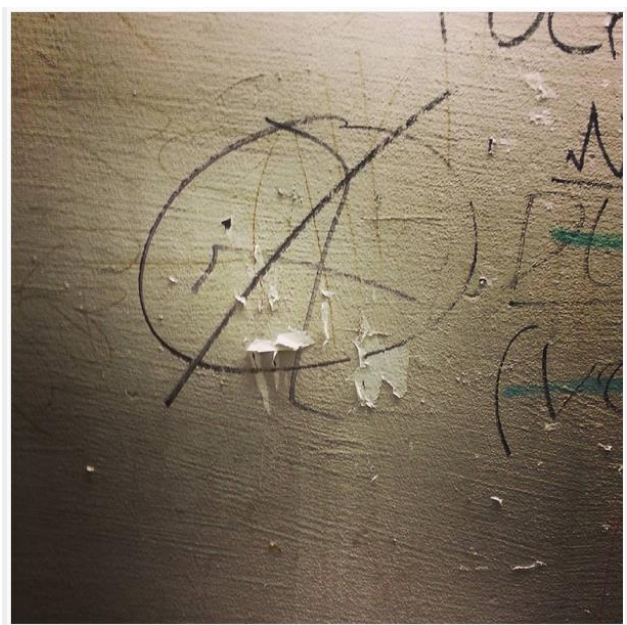

Figure 3: swagstudent Mirabellgarten; \#notmysymbol \#unisalzburg \#newproject \#university \#joinus \#forbiddencharacter \#salzburg https://www.instagram.com/p/BNuksW4Dnn3/ (access: 2017-01-31)

\footnotetext{
${ }^{8}$ Based on the thoughts of Hard (1989, S. 41), we developed a set of questions for the interpretation of traces, with the application in pedagogics in mind.
} 
In both images we see a swastika, but in Figure 3 the swastika is changed so that it looks like a symbol drawn by anarchists, who, in general, mobilize against right-wing extremist ideology and symbols. The intentions of the two symbols may be completely opposite to each other, but without knowing the original intention, all we can do is interpret the images as 'traces'. It is important to search for at least one other hypothesis and look for evidence supporting all hypotheses (Hard, 1995, p. 62; Kanwischer, 2015).

The process of reflexivity is quite demanding. We can see this in several comments from students. In several cases, they were insecure about whether a symbol was created with the intention of a right-wing extremist production of space or as a protest against it, for example:

I found a devil, who was performing a Hitler salute, which is definitely a matter of the Probibition Act. I also found writings which displayed the word 'Nari'. I wasn't quite sure whether the word was already forbidden, so I researched the probibited national socialist symbols.

(comment of a student, male; own translation)

Gordon, Mitchell \& Elwood (2016) have shown that critical spatial thinking can even foster civic engagement. An initial indication of this can be found in the following comment, where a student claims to have become more sensitized to right-wing extremist symbols in public space:

It was quite a positive experience for me. The process of searching for such symbols broadened my horizon and I think that I will now walk, the city with eyes open. If I find national-socialist symbols in the future, I will definitely report them to the authorities.

(comment of a student, male; own translation)

\section{$5 \quad$ Linking pedagogical foundation and technical implementation}

The following points formed the basis of the implementation. (1) The inquiry to identify existing symbols with photos should be based on crowdsourcing principles and therefore allow open, participatory collaboration. (2) The photos collected should be georeferenced to enable a cartographic visualization of all identified items. (3) Due to the sensitive nature of the topic, storage of the illegal symbols on university servers should be avoided. Given these requirements, it soon became evident that the use of a combination of technologies was desirable - i.e. a combination of social media, existing online services, cloud platforms and cloud applications, which allow for the required openness but which in addition - due to their terms of operation - are subject to national law principles.

Instagram was chosen as the social media platform to collect and publish the symbols found in public spaces. Anybody who wants to participate in the initiative can do so by: (1) photographing the symbol in situ using an ordinary smartphone, with the geo-tagging function in the camera's apps enabled, and (2) publicly posting the photo in combination with the hashtag '\#notmysymbol' and a clearly stated comment of disagreement. This has at least three advantages. (1) Immediately after a photo is posted, it is visible and available to a broad community. A 'realtime' collection of all posted symbols can be accessed via the 
Instagram integrated hashtag inquiry. ${ }^{9}$ (2) Instagram uses background geotags to add a location to every photo posted. This facilitates the geovisualization of all posts. (3) Instagram itself is a well-known and commonly used social media platform and so can serve as a multiplier for the initiative.

Additionally, it is possible to access specific Instagram posts through various filters (in this case the hashtag \#notmysymbol) and to geovisualize them in realtime via the ESRI GeoEvent Processing extension ${ }^{10}$ using the geo-tags of the posts. The images can be visualized in an ArcGIS Online webmap and can later be embedded in a specifically designed storymap ${ }^{11}$ showing the overall results of the initiative.

Using this approach, it is possible to address and transfer this topic into various post) secondary educational settings, using the pedagogic foundations described in section 4 . Teachers can participate in the initiative, using it in their lessons without the need to prepare the background infrastructure: in line with the three competence domains addressed in the 'Spatial Citizenship' approach (Gryl \& Jekel, 2012), the lesson(s) can focus on the collection of symbols using everyday technology, reflection on the inquiry itself and the emergence of the symbols, and the communication of the traces discovered, including via cartographic visualization (see Figure 4 for an overview).

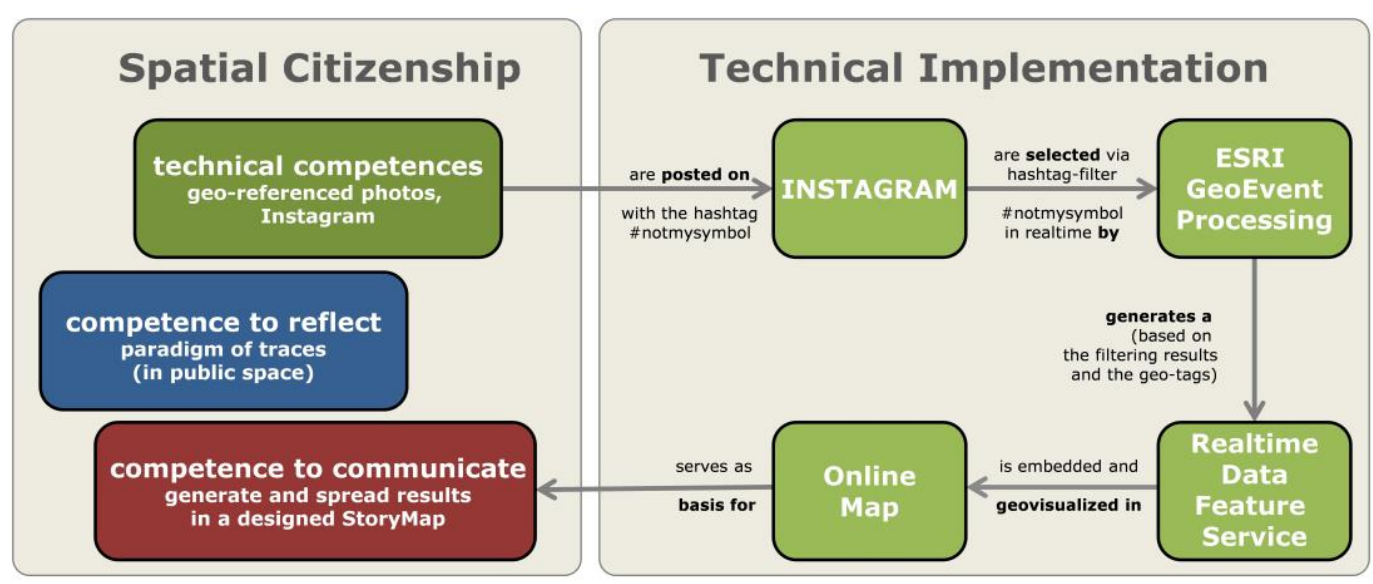

Figure 4: The structure of the \#notmysymbol initiative. Source: authors' own graphic.

\footnotetext{
${ }^{9}$ https://www.instagram.com/explore/tags/notmysymbol

${ }^{10} \mathrm{http://www.esri.com/arcgis/products/geoevent-server}$

${ }^{11}$ https://storymaps.arcgis.com/
} 


\section{Discussion and Conclusion}

The design of the initiative \#notmysymbol has great potential to foster critical spatial thinking in relation to civic engagement, as we illustrated with the comments from students in section 4. Overall, we think that the design, with its roots in concepts like Spatial Citizenship Education (Gryl \& Jekel, 2012) and Activist Citizenship Education (Gordon, Mitchell \& Elwood, 2016), is transferable to topics other than right-wing extremism, without decreasing the potential of the formation of the political subject.

The design of the initiative would have had even more critical and emancipatory potential if it had not focused so strictly on 'prohibited national socialist symbols'. ${ }^{12}$ Because they are not prohibited by law, this led to the initiative being blind to slogans such as 'foreigners out!' which are further evidence for extreme right-wing ideology within the paradigm of Rightwing Extremism as a Syndrome Phenomenon'. This critique was formulated by participating students themselves. If the project had been more oriented to the features of right-wing extremism generally as shown by Holzer (1994), the reflexivity process would have been more oriented towards reflexions on one's own political concept of 'right-wing extremism', rather than towards deciding whether a specific expression was forbidden or not. Future implementations will aim to take these considerations into account.

Another challenge was the collection of extreme right-wing symbols and how to 'exhibit' them in such a way as to demonstrate the strongest possible opposition to this ideology. We faced the reasonable argument that we would be duplicating the messages of the symbols through the collection process itself and especially through their 'exhibition' via Instagram. In shaping the '\#notmysymbol' hashtag, with its inherent personal opposition ('not my') to the symbols, we thought to address this challenge. Nevertheless, we understand the argument. It is a strange experience to face a collection of swastikas and other symbols of this nature, even if this is a result of an initiative against the ideology. For future projects, we will consider the technical possibilities of disfiguring the collected symbols with watermarks.

The experience we gained through this project suggests that it would be possible to derive further research projects from the initiative. The contribution to the formation of the political subject offered by collaborative mapping could serve as the focus of interest for future initiatives or research plans. One of these research plans could clearly link into the virtual landscapes of right-wing extremism in social media, and their spatialities, as the rightwing scene is increasingly changing its focus from public spaces to semi-public virtual spaces.

\footnotetext{
${ }^{12}$ It was deemed necessary in a first implementation, due to reasons of operationalization of the mapping process.
} 


\section{Acknowledgements}

We would like to thank all the students who contributed to the collecting and mapping processes. We are also grateful to Manfred Mittlböck, Bernhard Vockner \& Caroline Atzl (iSpace) as well as Claudia Schmidt (University of Salzburg) for their technical advice; to Andreas Peham (DÖW) and Jakob Hubauer (legal department University of Salzburg), and the Office for the Protection of the Constitution (Salzburg department) for their legal advice; and to the countless people with whom we discussed our work for their help and constructive criticism.

\section{References}

Abzeichengesetz 1960 (Österreich) idF von 2012. BGBl. I Nr. 113/2012.

Backes, U., \& Jesse, E. (1993). Politischer Extremismus in der Bundesrepublik Deutschland.

Bailer-Galanda, Brigitte (o.J). Zum Begriff des Rechtsextremismus.

http://www.doew.at/erkennen/rechtsextremismus/rechtsextreme-organisationen/zum-begriffdes-rechtsextremismus (Zugriff: 2017-01-03)

BMI - Bundesministerium des Inneren (2016). Verfassungsschutzbericht 2015.

https://www.verfassungsschutz.de/embed/vsbericht-2015.pdf (28.12.2016)

Brauckmann, S. (2015). 'How Do You Wish to Remember?' Youth Participation and

Culture of Remembrance Using Geo-Information. GI_Forum, 1, 251-260

BMBF - Bundesministerium für Bildung und Frauen (2015), Unterrichtsprinzip Politische Bildung, Grundsatzerlass. https://www.bmb.gv.at/ministerium/rs/2015_12.pdf?515357 (28.12.2016)

Carlos, V. \& I. Gryl (2013): Where do Critical Thinking and Spatial Citizenship meet? Proposing a framework of intersections. In: Jekel, T., A. Car, J. Strobl \& G. Griesebner (eds.): GI_Forum 2013. Creating the GISociety. Berlin: Wichmann, 437-446.

Deninger, D. (1999). Spurensuche: Auf der Suche nach neuen Perspektiven in der Geographie- und

Wirtschaftsdidaktik. In Vielhaber, C. (Ed.), Geographiedidaktik kreuz und quer. Vom

Vermittlungsinteresse bis zum Methodenstreit - Von der Spurensuche bis zum Raumverzicht. Vienna:

Universität Wien Institut für Geographie und Regionalforschung, pp. 107-184

Der Standard (5.11.2016), Salzburg: Männer lassen Drachen mit Nazisymbolen steigen. Verfügbar: http://derstandard.at/2000047008982/Salzburg-Maenner-liessen-Drachen-mit-NS-Symbolensteigen (21.12.2016)

Dokumentationsarchiv des österreichischen Widerstandes (2016), Digital Memory

Taking the DÖW Archive to the Streets. Verfügbar:

http:/ /www.doew.at/erforschen/projekte/datenbankprojekte/digital-memory (10.1.2017)

Elwood, S. and Mitchell, K.(2013). Another Politics is Possible: Neogeographies, Visual Spatial

Tactics and Political Formation. Cartographica (48)4, 275-292

erinnern.at (o.J.), http://www.erinnern.at/bundeslaender/oesterreich (10.1.2017)

Frindte, W., Geschke, D., Haußecker, N., \& Schmidtke, F. (2016). Rechtsextremismus und

`Nationalsozialistischer Untergrund . Interdisziplinäre Debatten, Befunde und Bilanzen. (W.

Frindte, D. Geschke, N. Haußecker, \& F. Schmidtke, Eds.). Wiesbaden: Verlag für

Sozialwissenschaften.

Fuchs, C. (2016). Rassismus, Nationalismus und Rechtsextremismus online: Die österreichische

Präsidentschaftswahl 2016 auf Facebook. Momentum Quarterly - Zeitschrift Für Sozialen

Fortschritt, 5(3), 172-196.

Glaser, M. (2012). >Rechtsextremismus - eine Begriffsdiskussion. Berlin: Kontaktstelle BIKnetz --

Präventionsnetz gegen Rechtsextremismus. 
Glaser, S. (2016). Multimedialer Hass - Medienpädagogische Workshops zur Auseinandersetzung mit Rechtsextremismus im Web. In: S. Braun et al. (Hrsg.), Strategien der extremen Rechten. Wiesbaden: Springer Verlag, 631-638

Gordon, E., Elwood, S. and Mitchell, K. 2016. Critical Spatial Learning: Participatory Mapping, Spatial Histories, and Youth Civic Engagement. Children's Geographies, 558-572 doi: $10.1080 / 14733285.2015 .1136736$

Griffin, R. (1991). The Nature of Fascism. New York: St. Martin's Press.

Gruenewald, D.A. (2003), The Best of Both Worlds: A Critical Pedagogy of Place. Educational Researcher, 32, 4, 3-12.

Gryl, I. \& Jekel, T. (2012), Re-centering GI in secondary education. Towards a spatial citizenship approach. In: Cartographica 47,1, 18-28.

Hard, G. (1995): Spuren und Spurenleser. Zur Theorie und Ästhetik des Spurenlesens in der Vegetation und anderswo. Osnabrück. Osnabrücker Studien zur Geographie, Bd. 16.

Harvey, F. (2013), A new Age of Discovery: The Post-GIS-Era. In: GI_Forum, 1, 272-281.

Hintermann, C. \& Pichler, H. (2015), Gendered Spaces in the City: Critical Topography in Geography Education. In: GI_Forum, 3, 287-298.

Holzer, W. (1994). Rechtsextremismus. Konturen, Definitionsmerkmale und Erklärungsansätze. In Dokumentationsarchiv des österreichischen Widerstandes (Ed.), Handbuch des österreichischen Rechtsextremismus (pp. 12-96). Wien.

Jaschke, H.-G. (1991). Streitbare Demokratie und innere Sicherheit. Opladen: Westdeutscher Verlag. Jaschke, H.-G. (1994). Rechtsextremismus und Fremdenfeindlichkeit. Opladen. Westdeutscher Verlag. Jekel, T., Gryl, I. \& Schulze U. (2015), Education for Spatial Citizenship. In: Muniz-Solari, O., Demirci, A. \& van der Schee, J., Geospatial Technologies and Geography Education in a Changing World. Tokyo: Springer, 35-49.

Jekel, T., Gryl, I., Oberrauch, A. (2015): Education für Spatial Citizenship: Versuch einer Einordnung. In: GW-Unterricht 137 (1), 5-13.

Jesse, E. (2004). Formen des politischen Extremismus. In BMI (Ed.), Extremismus in Deutschland (pp. 7-25).

Kanwischer, D. (2015) Spuren lesen und geographische Bildung. Didaktische Anmerkungen zu Gerhard Hard 1995: Spuren und Spurenleser. Zur Theorie und Ästhetik des Spurenlesens in der Vegetation und anderswo. geographische revue, 16, 1, 79-89

Kraushaar, W. (1994). Extremismus der Mitte. In H.-M. Lohmann (Ed.), Extremismus der Mitte : Vom rechten Verständnis deutscher Nation. Frankfurt a.M.: Fischer, pp. 23-50

Kreis, J. (2007). Zur Messung von rechtsextremer Einstellung: Probleme und Kontroversen am Beispiel zweier Studien. Berlin: Otto-Stammer-Zentrum.

Marsh, M, Golledge, R. \& Battersby S.E. (2008), Geospatial Concept Understanding and Recognition in G6-College Students: A Preliminary Argument for Minimal GIS. In: Annals of the Association of American Geographers, 97, 4, 696-712.

Peham, A. (2016). Rechtsextremismus als politische und pädagogische Herausforderung. Verfügbar: http://www.doew.at/neues/andreas-peham-rechtsextremismus-als-politische-und-paedagogischeherausforderung (10.1.2017)

Pfahl-Traughber, A. (2013). Jahrbuch für Extremismus- und Terrorismusforschung 2013.

Pfahl-Traughber, A. (2013). Kritik der Kritik der Extremismustheorie. Eine Auseinandersetzung mit einschlägigen Vorwürfen. In Pfahl-Traughber, A. (ed.). Jabrbuch für Extremismus- und Terrorismusforschung 2013, Brühl: Fachhochschule des Bundes für öffentliche Verwaltung, pp. 31-56

Pokraka, J., Gryl, I,, Schulze, U., Kanwischer, D. \& Jekel, T. (2017 in print), Promoting Learning and teaching with geospatial technologies using the Spatial Citizenship approach. In: Leite, L., Dourado, L., Afonso, A., and Morgado, S. 2017 (eds.), Contextualizing Teaching to Improving Learning: The case of Science and Geography

Pokraka, J.; Könen, D., Gryl, I. \& Jekel., T. (2016) Raum und Gesellschaft : Spatial Citizenship als 
Integration von Medien-, geographischer und politischer Bildung. In: Kuckuck, M., \& Budke, A. (eds), Politische Bildung im Geographieunterricht.. Stuttgart: Franz Steiner Verlag, 77-87

Rajal, E \& Schiedel, H (2016). „Rechtsextremismusprävention in der Schule: Ein ambitioniertes

Programm.' In FIPU (Ed.), Rechtsextremismus: Prävention und politische Bildung (pp. 85-137).

Schiedel, H. (2014). 'National und liberal verdrägt sich nicht.' In FIPU (Ed.), Rechtsextremismus:

Entwicklungen und Analysen (pp. 113-144).

Schlemmer, T., \& Woller, H. (2014). Der Faschismus in Europa. Wege der Forschung. (T. Schlemmer \& H. Woller, Eds.). München: de Gruyter Oldenbourg.

Schulze, U., Gryl, I. \& Kanwischer, D. (2015): Spatial Citizenship education and digital geomedia: composing competences for teacher education and training. In: Journal of Geography in Higher Education. 39, 3, 369-385.

Verbotsgesetz 1947 idF von 1992. BGBl. Nr. 148/1992.

Virchow, F., Langebach, M., \& Häusler, A. (2016). Handbuch Rechtsextremismus. Springer-Verlag.

Vogler, R., Hennig, S. \& Lindner-Fally, M. (2015): Shrinking technical Challenges - Zur strukturierten Erstellung digitaler Karten im Unterricht. In: GW-Unterricht 137(1), 49-60. http://www.gwunterricht.at/images/pdf/gwu_137_49_60_vogler_henning_lindner_fally.pdf

Weidinger, B. (2014). Zwischen Kritik und konservativer Agenda. Eine Verteidigung des

Rechstextremismusbegriffs gegen seine Proponent*innen. In FIPU (Ed.), Rechtsextremismus.

Entwicklungen und Analysen (pp. 69-90).

Werlen, B. (2008). Sozialgeographie. Bern: UTB 